UDC 378.4

DOI https://doi.org/10.30839/2072-7941.2018.155559

\title{
BENEFITS OF BUSINESS AND UNIVERSITY COLLABORATION IN CURRICULUM DEVELOPMENT
}

\author{
(C) MEJERYTE்-NARKEVIČIENE், K. \\ Lithuanian Sports University (Kaunas, Lithuania) Vytautas Magnus \\ University (Kaunas, Lithuania) \\ E-mail: kristina.mejeryte@1su.lt, ORCID 0000-0003-0629-3265
}

\begin{abstract}
The relevance of the research In the face of increasing global competition, business was challenged to seek new methods for creating their competitive advantage and at the same time the decreasing budgets of higher education institutions were pressured to find new streams of financing. In both cases, collaboration is seen as an important method for achieving their objectives but universities of today have as well to find the appropriate balance between teaching, basic and applied research, and entrepreneurship. Ten types of university-business collaboration are related quite directly to the missions of the university and the needs of business. Curriculum development and delivery is one of that ten, which aim is to develop human resources to modern society. A summary of benefits was identified in the academic literature as arising from UBC in relation to curriculum design and delivery for multiple stakeholders including academics, students, university administration, business and community. Overall, UBC may take various forms that are influenced by different factors but even if all stakeholders seeks the main purpose of this process they may get different benefits. The research aim was to identify the benefits of universities and business organizations in curriculum development. The objectives of the research: to determine the instruments and activities used for universities and business organizations collaboration, to identify universities and business organizations benefits from collaboration to the various stakeholder groups. Analysis of recent research and publications. UBC became the subject of education and management sciences. P. D'Este and M. Perkmann explored the factors of UBC, the types were identified by T. Davey, T. Baaken, V. Galan Muros, A. Meerman, T. Barnes, A. Gibbons and the levels of UBC were represented by B.N. Ponomariov, P.C. Boardman, T. Davey, R. Laužackas. The benefits of UBC to research quality have been studied by researchers T. Davey, M. Crespo, N. Carayol, H. Forsyth, R. Laxton, S. Lamichhane, T. Nath Sharma, P. Van der Sijde and H. Dridi, as a collaborative factor for learning improvement by researchers K. Ramakrishnan, N.M. Yasin, A. Draghici. An overview of the study of this object shows that it was mostly analysed in vocational training and in last ten years' period the publications is growing in UBC. Research methodology. The paper seeks to represent the UBC benefits for different stakeholders and collaboration forms, which was used by university with the business organizations from leisure industry. Quantitative research was used to gain quantify opinions of benefits and instruments of UBC - and generalize results from a larger sample population. Methods applied for the research was scientific literature review, a questionnaire survey for business organization leaders and mathematical statistics.

Conclusion. The benefits of the UVB were grouped according to the type of stakeholder's: society, university administration, academics, entrepreneurs, students. The benefits of business stakeholders include additional funding, access to education resources, lecturer and coordinator, support in evaluating the program and developing new study subjects. The highest rated benefit to others stakeholders from their view could be reducing academic staff training costs, as well as business information available to student projects,
\end{abstract}

(C) Mejerytė-Narkevičienė K., 2018 
skills development and student employment opportunities and human resource development in the region.

Keywords: university and business collaboration, UBC benefits, UBC collaboration forms, curriculum performance, business collaboration in curriculum.

\section{University and business} collaboration benefits in curriculum development.

In the political and scientific area, UBC is increasingly becoming the subject of heated debate and it has different meanings for both parties. An overview of scientific literature has shown that for academicians best appreciated advantage in collaboration with the business is reach the knowledge in practice, integrate that information into the higher education system, obtain funds for research or find the sponsors [4]. From the business position, the collaboration has been a shift toward the acquisition of knowledge with an academic base, which can then be transformed into production [14]. This helps business organizations to compete with others in the industry. For a long time, entrepreneurship, the provision of commercial services, and cooperation with business enterprises have not been linked to the academic world. The universities, business and governments now are interested in good and effective collaboration which would be beneficial for all sides.

UBC collaboration and a lot of knowledge transfer cases between universities and business was conducted through various channels and practices [7, 13, 10, 18]. The biggest impact for the further development of UBC was made in 2011 [5], the project "University
Business Cooperation in Europe" get a funding and during this project the UBC was analysed in all Europe countries.

According to this an extensive study among European universities [5] and other studies [6, 22, 28], there were identified ten types of UBC, which are related quite directly to the missions of the university (Education, Research and Entrepreneurship) and the needs of business (Entrepreneurs, Qualified employees, Innovation, Turnover and profit): Curriculum development and delivery, Lifelong learning, Student mobility, Academic mobility, Commercialization in $R \& D$, Entrepreneurship, Governance, Resource (facilities, equipment \& data), Sharing and popularization of science in the Media. Five forms of outlined collaboration are particular relevance to education collaboration, although all of them can play an important role.

Collaboration between universities and businesses can be in various types and at the various levels, it is also taking place in different ways, depending on the type of institution involved, and the specifics of the individual areas of science. It can argued that relationships are often supported by a variety of communication mechanisms, such as research collaboration, industrial contribution to the development of study programs, student support and recruitment, and the exchange of 
scientific staff [20]. There is also the cultural divide between how universities and business operate [17], think and behave [19]. As long as there is mutual benefit, an access to expert researchers with innovative capacity and a needed stream of funding for universities, the collaborations between universities and business will continue.

A series of benefits for European UBC were identified through literature but the importance and benefits of collaboration between universities and business in this context is seen due to its effects for various stakeholder groups $[4,9,19$, 27]: academics, students, university administration, business and community.

Most noted benefits in the literature for the community were growing employability, growing local gross, domestic product and disposable income, social and recreational benefit creation [6].

The benefits for the administration according to the other researchers were are ability to improve the quality of studies, the emergence of innovation, availability for additional government and business funding [3], possibility of implementation of the university missions [6]. The most significant benefit for the university is that recent interactions between business have brought academic science closer to business [8].

The academics in collaboration with the business increase the competence in the business world, informs teaching curriculum design and delivery [4, 19], provides inspiration for teaching [27], provides understanding of companies as well as the current challenges and management topics [12], helps to become an important part with their research, increase the possibilities for additional funding and employability [6].

There is increasing pressure from government on universities to provide opportunities for higher education students to acquire and develop the skills and attributes required by business. During UBC students exposure to interesting and relevant "Real world" problems adding a valuable dimension to learning process, provides current and future employment opportunities [1, 7, 18, 19, 23], improves preparation for future professional challenges in industry [2, 6], increase practical skills knowledge and experience [4, $18,27]$, provides industry mentors from industry for developing future career ladders [16], improves quality of his experience [9], improves learning experience [6] and the student's competence corresponds more to the business world.

According to the business it seems that collaboration with the university provides candidates for internship [24], allows identification of talented young people with the best fit in: to increase their competitiveness and innovation $[9,12]$, brings new skills, fresh enthusiasm and new perspectives, reduces cost in hiring, improves attractiveness as prospective employers [12], improves relevance of education to industry [9], might get additional government funding, increase revenue from licenses [3], 
increase business efficiency and improves business performance [6].

Universities collaboration with the business in curriculum development has received very little academic attention [25], despite its widespread practice [5, 15], and its ability to enrich education [4, 9]. The curriculum delivery is still seen as the delivery of programs, courses and content to the students via a large range of mechanisms [5]. A lot of growing reports about the benefits [5, $21,26]$ relating to business and universities co-designing and codelivering curricular and developing practices aimed at supporting such collaborations, there was also investigated the instruments driving business engagement in curriculumrelated activities and achieving an alignment of business needs with universities offers [22]. Even if the collaboration of universities with the business was analysed in different levels, the emerging problems is still addressed to the university or business organization itself or their members.

The business organizations rely on universities to deliver qualified and skilled employees and universities rely on business to provide work placements for their students and to employ their graduates [22]. Now universities face strong pressures to marry theoretical understanding with real-life practice to ensure high levels of graduate employability $[11,22]$ by advancing and modernising their curricula. So all types of the university and business collaboration relays also on curriculum development. The most successful partnerships are built on trust, having a common vision and seeing mutual benefits.

UBC benefits for all stakeholders illustrates that are many ways in which businesses and universities could work together. The most important thing in curricular development is that the business engaged in curriculum design, curriculum delivery and curriculum evaluation. Engaging with the universities in curricular design, delivery and evaluation not only allows business to influence the education of the future workforce but engage with prospective future employees throughout their educational experience [22].

\section{Research methodology}

Based on a thorough literature review were identified universities and leisure organizations benefits in curriculum development. For this study purpose it was organized the quantitative research with the Lithuanian Sports university (LSU) social partners from business leisure organizations. Quantitative research was used to gain quantify opinions of benefits of UBC - and generalize results from a larger sample population. This research is based only on the opinion of leisure business organizations leaders who are the LSU social partners. LSU has 221 social partners but only 24 are from business organizations. All the 24 leisure business organization leaders were asked to participate and fulfil the survey questionnaire as the respondents for this research from October to December of 2017. Questionnaire was used as data 
collection instrument and the benefits were divided according the group of the stakeholders. In questionnaire it was used the five point Likert-scaled ranging. The validity of questionnaire was checked by two senior and well experienced educators of Sport management, economy and sociology department. Data of the research was processed by mathematical analysis.

\section{Results}

The research results showed that the minority of business organization leaders from the leisure industry thinks that the bets benefit of UBC to community (Figure 1) is growing employability $(4,58)$ and that it helps to improve the regional productivity $(4,33)$. The less important benefit according business is the growing local gross $(3,62)$. This confirms that there is a strong link between growing employability and growing student's employability which is higher if the university collaborates with the business during students practises and etc.

Figure 1. UBC benefits for community.

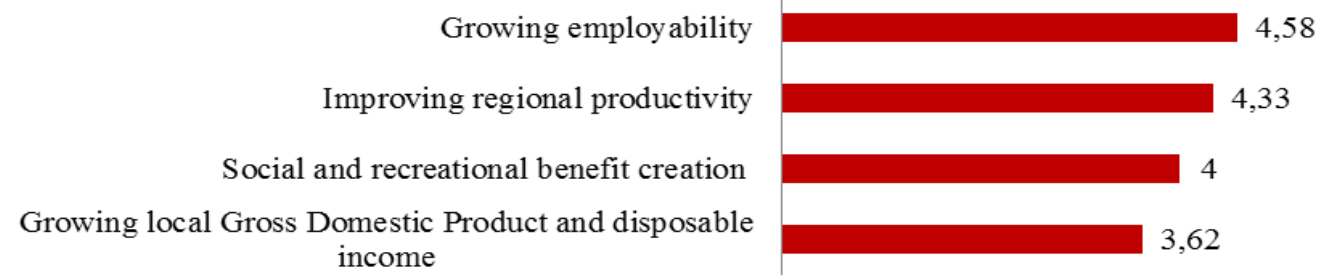

The Figure 2 shows that business missions $(3,12)$. The most benefit organizations don't see a lot of benefits for university administration. The least benefit obtained from UBC according to business it could be implementation of the university obtained from the UBC are additional government and business funding $(4,37)$ and possibility to improve the quality of studies $(4,33)$.

Figure 2. UBC benefits for administration.

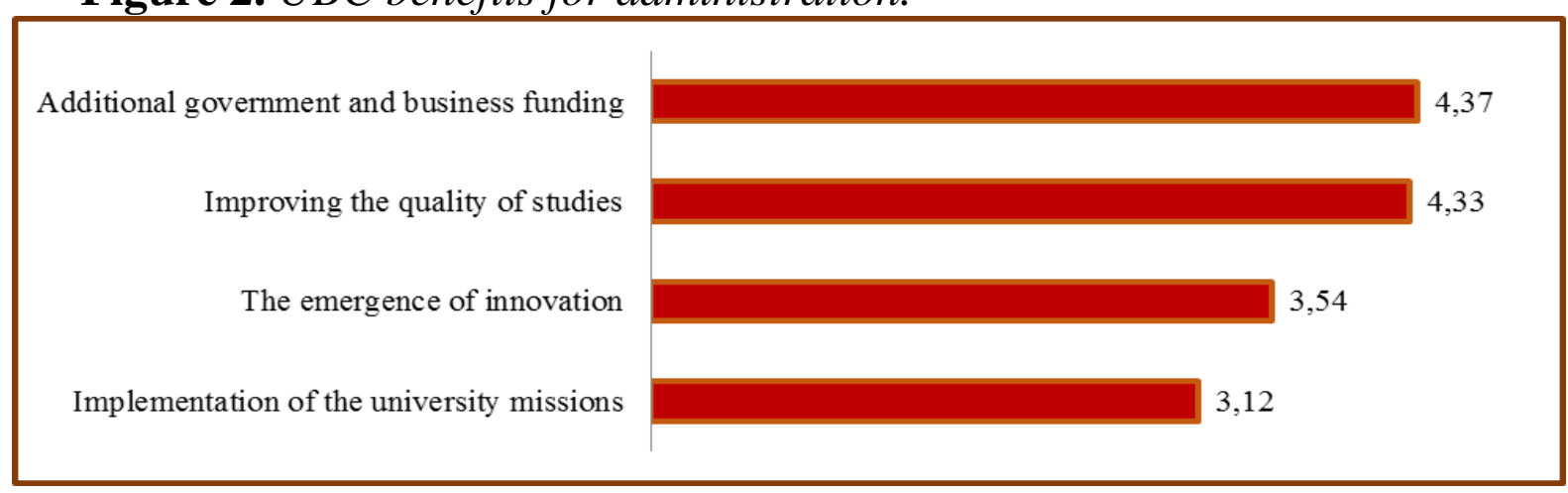

The benefits for academics is academics is to increase the shown in Figure 3. According to the possibilities for additional funding results the maximum benefit for and employability $(4,83)$, provide (O) Mejerytè-Narkevičienè K., 2018 
understanding of companies as well as the current challenges and management topics $(4,58)$. Leisure industry business leaders don't think that the UBC could provide the inspiration for teaching $(2,91)$ or academics become an important part with their research in the business $(2,7)$.

Figure 3. UBC benefits for academics.

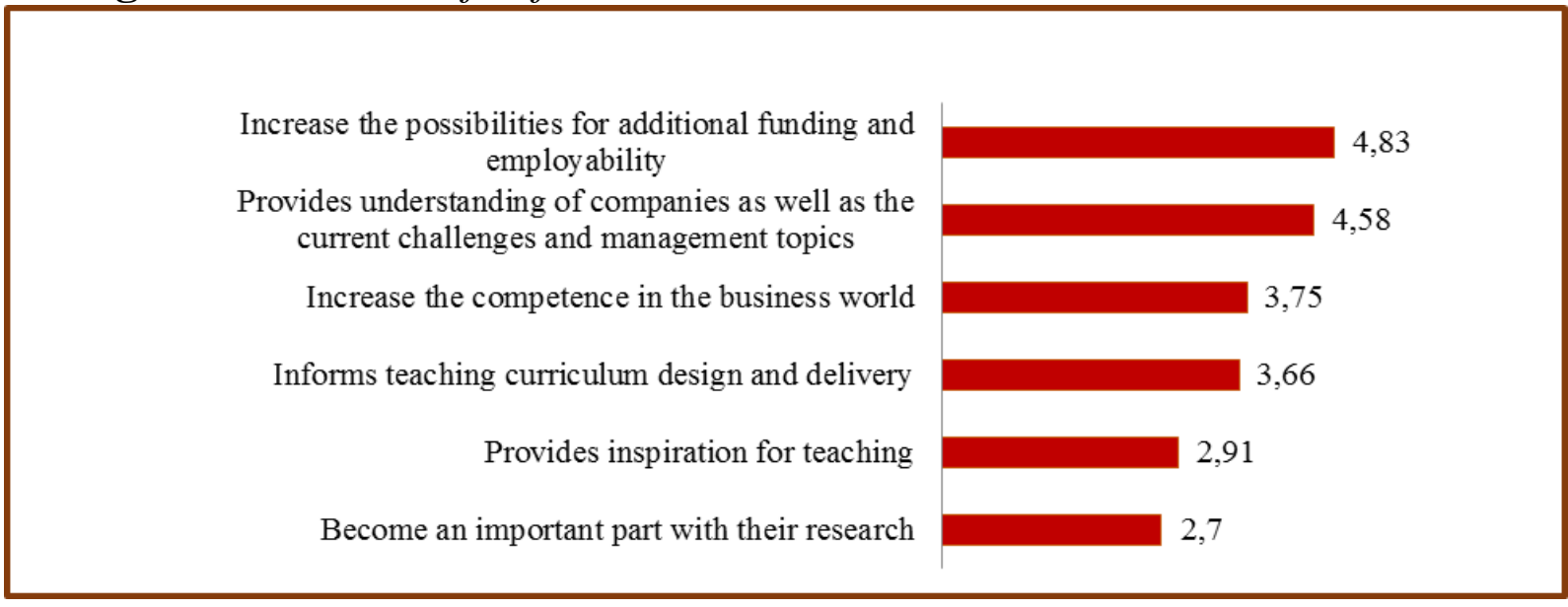

Most appreciated benefits of university and business collaboration evaluated by business were for students. Figure 4 shows that leisure industry business leaders see the greatest benefits for students to increase their practical skills, knowledge and experience (5), it is opportunity to improve the quality of his experience $(4,79)$ and as well helps to improve the learning experience $(4,37)$. The less important benefit according business is the UBC helps to improve the student's preparation for future professional challenges in industry $(3,62)$.

Figure 4. UBC benefits for students.

\begin{tabular}{|r|r|}
\hline Increases practical skills knowledge and experience & \\
Improves quality of his experience & 4,79 \\
Improves learning experience & 4,37 \\
Provides industry mentors from industry for developing & 4,2 \\
future career ladders & 4,08 \\
The student's competence corresponds to the business \\
world
\end{tabular}

The last group was the benefits of UBC for the business. As you can see in the figure 5 the most appreciated benefits were that UBC helps to reduce the cost of hiring $(4,87)$, the business can get the government Benefits of business and university collaboration in curriculum development 
funding $(4,87)$, helps to improve the attractiveness employers $(4,58)$ and provides candidates for the internship $(4,58)$. According to the leisure industry business leaders (LSU social partners) the collaboration with the university do not achieve the increasing revenue from licenses $(1,04)$ and as well do not improve the relevance of education to industry or business $(2,91)$.

Figure 5. UBC benefits for business (leisure organisations).

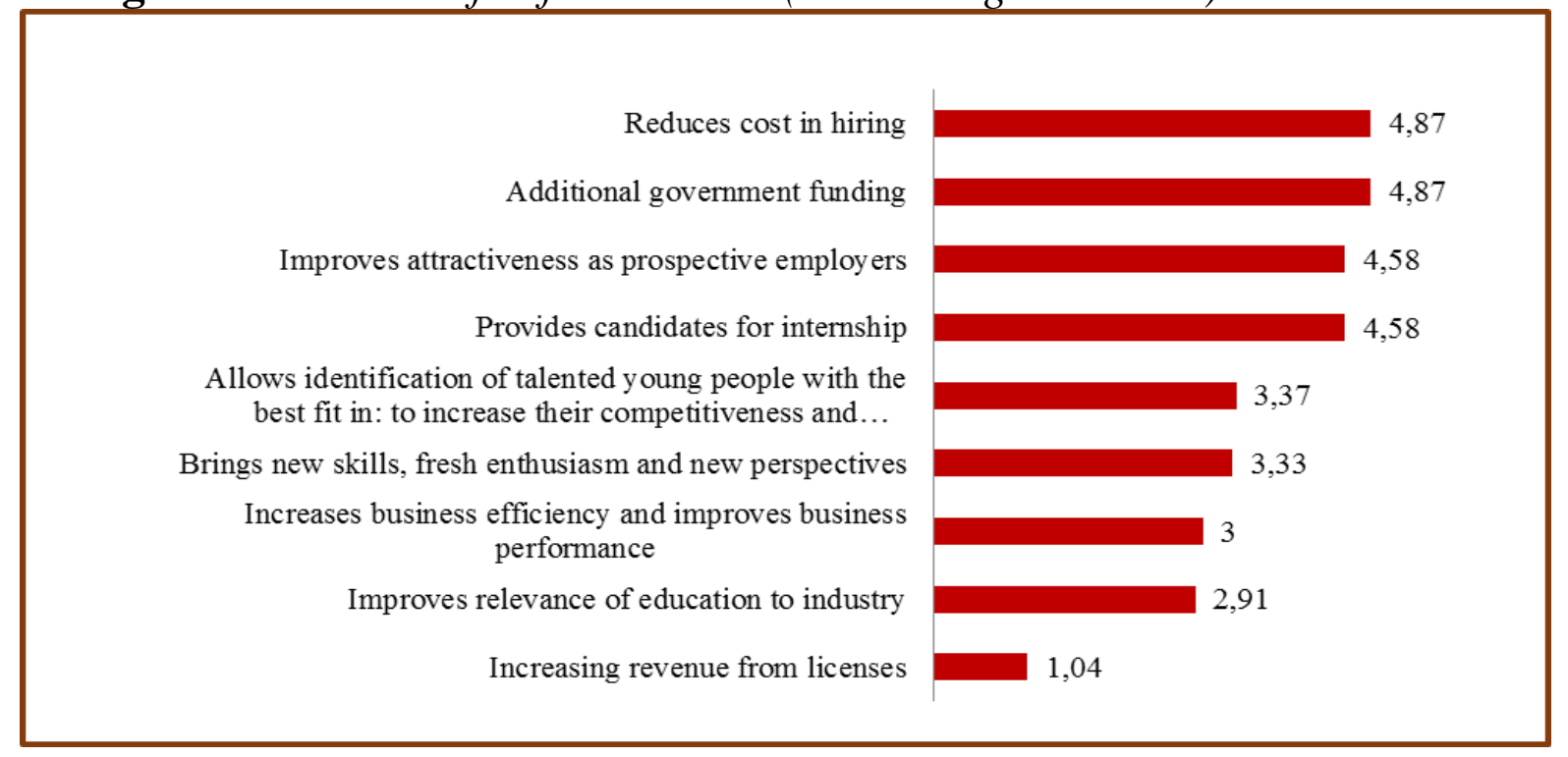

According to the research results it seems that the business knows the benefits for all the stakeholders of the university, but probably university has to build stronger links with business, suggesting that business should be more involved in all collaboration forms and especially in curriculum performance and licenses. Business still need to extend the UBC types in their organizations, engage in more activities which are very important for curriculum development and use all instruments/methods they could.

\section{Conclusion}

The most commonly established collaboration instruments during university and leisure business organizations were guest lecturers, internships, student's consultations for final papers and being the member of the study program committee. The benefits of the UVB were grouped according to the type of stakeholder's: society, university administration, academics, entrepreneurs, students. The benefits of business stakeholders include additional funding, access to education resources, lecturer and coordinator, support in evaluating the program and developing new study subjects. The highest rated benefit to others stakeholders from their view could be reducing academic staff training costs, as well as business information available to student projects, skills development and student employment opportunities and human resource development in the region. 


\section{REFERENCES}

1. Benneworth, P., Jongbloed, B. W. (2009). Who matters to universities? A stakeholder perspective on humanities, arts and social sciences valorisation. Higher Education, 59 (5), 567-588. doi: https://doi.org/10.1007/s10734-009-9265-2

2. Bersènaitè, J. (2016). Verslo imonių vystymosi trajektorijos bendradarbiaujant su mokslo ir studijų institucijomis. Šiauliai, 236.

3. Barnes, T., Pashby, I., Gibbons, A. (2002). Effective University - Industry Interaction: European Management Journal, 20 (3), 272-285. doi: https://doi.org/10.1016/s02632373(02)00044-0

4. Carayol, N. (2003). Objectives, agreements and matching in science-industry collaborations: reassembling the pieces of the puzzle. Research Policy, 32 (6), 887-908. doi: https://doi.org/10.1016/s0048-7333(02)00108-7

5. Davey, T., Baaken, T., Galan-Muros, V. (2011). The State of European UniversityBusiness Cooperation: Part of the DG Education and Culture Study on the Cooperation between Higher Education Institutions and Public and Private Organisations in Europe, 141.

6. Davey, T. (2017). Converting university knowledge into value: how conceptual frameworks contribute to the understanding of the third mission role of European universities. International Journal of Technology Transfer and Commercialisation, 15 (1), 65. doi: https://doi.org/10.1504/ijttc.2017.10005380

7. Dutrénit, G., De Fuentes, C., Torres, A. (2010). Channels of interaction between public research organisations and industry and their benefits: evidence from Mexico. Science and Public Policy, 37 (7), 513-526. doi: https://doi.org/10.3152/030234210x512025

8. Evans, J.A (2010). Industry collaboration, scientific sharing and the dissemination of knowledge. Social Studies of Science, 40(5), 757-791. [in English].

9. Forsyth, H., Laxton, R., Moran, C., van der werf, J., Banks, R., Taylor, R. (2008). Postgraduate coursework in Australia: issues emerging from university and industry collaboration. Higher Education, 57 (5), 641-655. doi: https://doi.org/10.1007/s10734008-9167-8

10. Garousi, V., Petersen, K., Ozkan, B. (2016). Challenges and best practices in industryacademia collaborations in software engineering: A systematic literature review. Information and Software Technology, 79, 106-127. doi: https://doi.org/10.1016/j.infsof.2016.07.006

11. Gillis, M., McNally, M. (2010). The influence of industry on dental education. Journal of Dental Education, 74 (10), 1095-1105.

12.Ginzburg, S., Houli, E. (2013). Collaboration between the Academic World and Industry. Tefen Tribune, Winter Issue, 19-22.

13. Golder-Buckley, D., Way, D., Glover, M., et. al. (2015). Best Practice Strategies for Successful Innovation through University-Business Collaboration, Research Councils UK.

14.Hagedoorn, J., Link, A. N., Vonortas, N. S. (2000). Research partnerships. Research Policy, 29 (4-5), 567-586. doi: https://doi.org/10.1016/s0048-7333(99)00090-6

15.Healy, A., Perkmann, M., Goddard, J.,Kempton, L. (2014). Measuring the impact of university-business cooperation. Catalogue No. NC-02-14-1337-EN-N. Luxembourg: Publications Office of the European Union.Huang, M.H.

16. Hedvall, M. (2011). University-industry collaboration \& degree mobility. EDAMBA \& Hanken School of Economics.

17.Ho, M. H.-C., Liu, J. S., Kuan, M. C.-H. (2016). Torn between Academic Publications and University-Industry Collaboration. Research Evaluation, 25 (2), 151-160. doi: https://doi.org/10.1093/reseval/rvw001

18.Ilyas, M. (2004). Best practices in industry-university collaboration. Government, industry and university relationships and collaboration. Published in the proceedings for the

Benefits of business and university collaboration in curriculum development 
Second LACCEI International Latin American and Caribbean Conference for Engineering and Technology (LACCEI'2004), Paper No. 037.

19.Lamichhane, S., Sharma, T. N. (2013). University - Industry Relations: A Thrust for Transformation of Knowledge and Economic Acceleration. Journal of Education and Research, 2, 59-66. doi: https://doi.org/10.3126/jer.v2i0.7624

20.Lam, A. (2007). Knowledge Networks and Careers: Academic Scientists in Industry?University Links. Journal of Management Studies, 44 (6), 993-1016. doi: https://doi.org/10.1111/j.1467-6486.2007.00696.x

21.Othman, R., Omar, A. F. (2012). University and industry collaboration: towards a successful and sustainable partnership. Procedia - Social and Behavioral Sciences, 31, 575579. doi: https://doi.org/10.1016/i.sbspro.2011.12.106

22.Plewa, C., Galán-Muros, V., Davey, T. (2014). Engaging business in curriculum design and delivery: a higher education institution perspective. Higher Education, 70 (1), 3553. doi: https://doi.org/10.1007/s10734-014-9822-1

23.Santoro, M. D., Chakrabarti, A. K. (2002). Firm size and technology centrality in industry-university interactions. Research Policy, 31 (7), 1163-1180. doi: https://doi.org/10.1016/s0048-7333(01)00190-1

24.Shahabudin, S. (2006). University-Industry Collaboration in Curriculum Development, Universiti Kebangsaan Malaysia. Available at: http://eprints.ukm.my/53/1/Session1-1-Prof.Shahabudin.pdf

25.Siegel, D. J. (2007). Building a pipeline for diversity through intersectoral collaboration. Higher Education, 55 (5), 519-535. doi: https://doi.org/10.1007/s10734007-9072-6

26.Stonkienè, M., Matkevičienè, R. (2014). Trečiosios universitetų misijos poveikis mokslo žinių sklaidai universitetinèse studijose. Societal Studies, 6 (3), 611-632. doi: https://doi.org/10.13165/sms-14-6-3-10

27.Van der Sijde, P. C. (2012). Profiting from Knowledge Circulation: The Gains from University-Industry Interaction. Industry and Higher Education, 26 (1), 15-19. doi: https://doi.org/10.5367/ihe.2012.0082

28.Wakkee, I. A. M., Van der Sijde, P., Nuijens, N. (2013). Valorisatie in Nederland:exploratieve verkenning van het landschap van valorisatieprogramma's'. Amsterdam: VU/FSW-Org (internal report).

МЕЙЕРИТЕ-НАРКЕВИЧЕНЕ, КРИСТИНА - викладач кафедри спортивного менеджменту, економіки та соціології, Литовський спортивний університет (Каунас, Литва), Університет Вітаутаса Великого (Каунас, Литва)

E-mail: kristina.mejeryte@ 1su.lt, ORCID 0000-0003-0629-3265

\section{ПЕРЕВАГИ СПІВПРАЦІ МІЖ УНІВЕРСИТЕТОМ І БІЗНЕСОМ 3 МЕТОЮ ПОКРАЩЕННЯ ЗМІСТУ НАВЧАЛЬНИХ ПРОГРАМ}

Анотація. Актуальність дослідження проявляється в тому, що переваги різних форм співпраці між університетами і бізнесом проявляються через різні зацікавлені сторони: громадськість, адміністрацію університету та його засновників, вчених, студентів i бізнесу. Десть типів співпраці UBC напряму пов'язані 3 місіями університетів та потребами бізнесу, які прямо чи опосередковано приносять користь обом організаціям. Це дослідження акцентує увагу на переважно співпраці між університетом і бізнесом через зміст, розробку, реалізацію та оцінку навчальних програм. Мета дослідження - виявити переваги співпраці університету та бізнесу у (C) Mejerytė-Narkevičienè K., 2018 
покращенні змісту навчання. Задачами дослідження $\boldsymbol{\epsilon}$ наступні: розробити інструменти і види діяльності, за допомогою яких університет співпрацює з бізнесом; ідентифікувати переваги співпраці між університетом та зацікавленими сторонами у покращенні змісту навчання. Аналіз останніх досліджень і публікацій. 3 формуванням третьої університетської місії співпраця між університетом і бізнесом широко аналізувалася не тільки у сфері управління, але й у сфері природничо-наукової освіти. P. D'Este and M. Perkmann досліджували переваги співпраці між університетом і бізнесом; такі типи співпраці були ідентифіковані Т. Davey, T. Baaken, V. Galan Muros, A. Meerman, T. Barnes, A. Gibbons; рівні співпраці між університетом і бзнесом були представлені вченими B.N. Ponomariov, P.C. Boardman, T. Davey, R. Laužackas. Більше того, переваги між університетом і бізнесом на різних рівнях досліджували T. Davey, M. Crespo, N. Carayol, H. Forsyth, R. Laxton, S. Lamichhane, T. Nath Sharma, P. Van der Sijde and H. Dridi, K. Ramakrishnan, N.M. Yasin, A. Draghici. Обзор дослідження свідчить, що це був аналіз навчання без відриву від виробництва і навчання без відриву від роботи в UBC. Методологія дослідження. Для аналізу об'єкта дослідження було обрано кількісне дослідження, у якому прийняли участь соціальні партнери Литовського університету спорту, що представляють організації бізнесу. Результати дослідження демонструють тільки думку представників бізнесу про переваги, які отримують зацікавлені сторони. Для дослідження було застосовано наступні методи: аналіз наукової літератури, анкетування і дослідження даних, які були оброблені математичним аналізом. Висновки. Перевага співпраці між університетом і бізнесом 3 метою покращення змісту програм навчання були розділені переважно зацікавленими сторонами: громадськість, адміністрація університету та його засновники, вчені, студенти i бізнес. Самою великою перевагою та зиском бізнесу $\epsilon$ можливість додаткового фінансування у рамках різних проектів у співпраці з університетом та перепідготовкою співробітників. Переваги вагомі і в співпраці між університетом i бізнесом у вигляді проведення лекцій студентам, участі у студентській практиці, покращення та оцінки змісту навчальних програм.

Ключові слова: університетсько-ділова співпраця, переваги співпраці університету та бізнесу, форми університетсько-ділової співпраці, покращення змісту програм навчання, співпраця бізнесу у змісті навчання.

МЕЙЕРИТЕ-НАРКЕВИЧЕНЕ, КРИСТИНА - преподаватель кафедры спортивного менеджмента, экономики и социологии Литовского спортивного университета (Каунас, Литва), Университет Витаутаса Великого (Каунас, Литва),

E-mail: kristina.mejeryte@1su.lt, ORCID 0000-0003-0629-3265

\section{ПРЕИМУЩЕСТВА СОТРУДНИЧЕСТВА МЕЖДУ УНИВЕРСИТЕТОМ И БИЗНЕСОМ С ЦЕЛЬЮ УЛУЧШЕНИЯ СОДЕРЖАНИЯ УЧЕБНЫХ ПРОГРАММ}

Аннотация. Актуальность исследования проявляется в том, что преимущества различных форм сотрудничества между университетами и бизнесом проявляются через различные заинтересованные стороны: общества, администрацию университета и его основателей, ученых, студентов и бизнеса. Десять типов сотрудничества UBC напрямую связаны с миссиями университетов и потребностями бизнеса, которые прямо или косвенно приносят пользу обеим организациям, Это исследование акцентирует внимание на преимуществе сотрудничества между университетами и бизнесом через содержание, разработку, реализацию и оценку содержания учебных программ.

Benefits of business and university collaboration in curriculum development 
Цель исследования - выявить преимущества сотрудничества университета и бизнеса в улучшении содержания обучения. Задачами являются: разработать инструменты и виды деятельности, с помощью которых университет сотрудничает с бизнесом; идентифицировать преимущества сотрудничества между университетом и заинтересованными сторонами в улучшении содержания обучения. Анализ последних исследований и публикаций. С образованием третьей университетской миссии сотрудничество между университетами и бизнесом широко анализировалось не только в области управления, но и в сфере естественно-научного образования. P. D'Este and M. Perkmann исследовали преимущества сотрудничества между университетами и бизнесом; типы сотрудничества были идентифицированы T. Davey, T. Baaken, V. Galan Muros, A. Meerman, T. Barnes, A. Gibbons; уровни сотрудничества между университетами и бизнесом были представлены учеными B.N. Ponomariov, P.C. Boardman, T. Davey, R. Laužackas. Больше всего о преимуществах сотрудничества между университетами и бизнесом на разных уровнях исследовали Т. Davey, M. Crespo, N. Carayol, H. Forsyth, R. Laxton, S. Lamichhane, T. Nath Sharma, P. Van der Sijde and H. Dridi, K. Ramakrishnan, N.M. Yasin, A. Draghici. Обзор исследования показывает, что это был анализ обучения без отрыва от производства и обучения без отрыва от работы в UBC. Методология исследования. Для анализа объекта исследования было выбрано количественное исследование, в котором приняли участие социальные партнеры Литовского университета спорта, представляющие организации бизнеса. Результаты исследования демонстрируют только мнение представителей бизнеса о преимуществах, которые получают заинтересованные стороны. Для исследования были применены следующие методы: анализ научной литературы, анкетирование и исследованием данных, которые были обработаны математическим анализом.

Выводы. Преимущество сотрудничества между университетами и бизнесом в улучшении содержания программ обучения были разделены по преимущчество получающим заинтересованным сторонам: общественность, администрации университета и его основатели, ученые, студенты и бизнес. Самым большим преимуществом и выгодой бизнеса является возможность дополнительного финансирования в рамках различных проектов при сотрудничестве с университетами и переподготовка сотрудников. Преимущества заметны и в сотрудничестве между университетами и бизнесом в виде проведения-лекций студентам, участия в студенческой практике, улучшения или оценки содержания учебных программ.

Ключевые слова: университетско-деловое сотрудничество, преимущества сотрудничества университета и бизнеса, формы университетско-делового сотрудничества, улучшение содержания программ обучения, сотрудничество бизнеса в содержании обучения.

Стаття рекомендована до публікаиії д.філософ.н., проф. В.Г.Воронковою (Запоріжжя, Украӥна)

Надійшла до редколегї: 12.12.2018 p. Прийнята до друку: 17.12.2018 p. 